\title{
Asiaticoside induces cell proliferation and collagen synthesis in human dermal fibroblasts
}

\author{
Linda Yulianti*,**, Etik Mardliyati****, Kusmarinah Bramono*****, \\ and Hans Joachim Freisleben**
}

\begin{abstract}
*Department of Dermatovenereology, Faculty of Medicine,

Tarumanegara University

**Biomedical Sciences Doctoral

Program, Faculty of Medicine,

University of Indonesia

$* * *$ Centre for Pharmaceutical and

Medical Technology,

Agency for the Assessment and

Application of Technology,

Ministry of Research, Technology, and Higher Education

\section{BACKGROUND}

Asiatiocoside, a saponin component isolated from Centella asiatica can improve wound healing by promoting the proliferation of human dermal fibroblasts (HDF) and synthesis of collagen. The skin-renewing cells and type I and III collagen synthesis decrease with aging, resulting in the reduction of skin elasticity and delayed wound healing. Usage of natural active compounds from plants in wound healing should be evaluated and compared to retinoic acid as an active agent that regulates wound healing. The aim of this study was to compare and evaluate the effect of asiaticoside and retinoic acid to induce greater cell proliferation and type I and III collagen synthesis in human dermal fibroblast.
\end{abstract}

$* * * *$ Department of

Dermatovenereology,

Faculty of Medicine,

University of Indonesia

\section{Correspondence:}

dr. Linda Yulianti Wijayadi, SpKK

Department of Dermatovenereology

Faculty of Medicine,

Tarumanegara University

Jalan LetJen. S.Parman No.1 Grogol

Jakarta Barat 11440

Email :

lindajuliantiwijayadi@gmail.com

Univ Med 2015;34:96-103

DOI: 10.18051/UnivMed.2016.v35.96-103 pISSN: 1907-3062 / eISSN: 2407-2230

This open access article is distributed under a Creative Commons Attribution-Non Commercial-Share Alike 4.0 International License

\section{METHODS}

Laboratory experiments were conducted using human dermal fibroblasts (HDF) isolated from human foreskin explants. Seven passages of HDF were treated with asiaticoside and retinoic acid at several doses and incubated for 24 and 48 hours. Cell viability in all groups was tested with the MTT assay to assess HDF proliferation. Type I and III collagen synthesis was examined using the respective ELISA kits. Analysis of variance was performed to compare the treatment groups.

\section{RESULTS}

Asiaticoside had significantly stronger effects on HDF proliferation than retinoic acid $(\mathrm{p}<0.05)$. The type III collagen production was significantly greater induction with asiaticoside compared to retinoic acid $(\mathrm{p}<0.05)$.

\section{CONCLUSION}

Asiaticoside induces HDF proliferation and type I and III collagen synthesis in a time- and dose-dependent pattern. Asiaticoside has a similar effect as retinoic acid on type I and type III collagen synthesis.

Keywords: Asiaticoside, type I collagen, type III collagen, fibroblast, proliferation, retinoic acid 


\section{Asiaticoside menginduksi proliferasi sel dan sintesis kolagen pada fibroblas dermis kulit manusia}

\section{ABSTRAK}

\section{LATAR BELAKANG}

Asiatiocosida merupakan komponen saponin yang diisolasi dari Centella asiatica yang bermanfaat untuk mempercepat penyembuhan luka dengan meningkatkan proliferasi dan sintesis kolagen dalam fibroblas dermis kulit manusia. Proses pembaharuan sel kulit dan sintesis kolagen tipe I dan III menurun dengan proses penuaan, elastisitas kulit berkurang dan penyembuhan luka melambat. Penggunaan senyawa aktif alami dari herbal dalam penyembuhan luka dievaluasi dan dibandingkan dengan asam retinoat sebagai bahan aktif yang mengatur penyembuhan luka. Tujuan penelitian ini adalah untuk membandingkan dan mengevaluasi pengaruh asiaticosida dan asam retinoat terhadap proliferasi fibroblas dan sintesis kolagen tipe I dan III pada dermis kulit manusia.

\section{METODE}

Sebuah penelitian eksperimental laboratorik menggunakan sel dermis fibroblas kulit manusia yang diisolasi dari eksplan kulit. Generasi ke tujuh fibroblas dermis kulit manusia dipajankan dengan beberapa dosis asiaticosida dan asam retinoat, diinkubasi selama 24 dan 48 jam. Viabilitas sel diuji dengan uji MTT untuk menilai proliferasi fibroblas kulit manusia. Sintesis kolagen Tipe I dan III diperiksa menggunakan ELISA kit, masing-masing dievaluasi setelah 24 dan 48 jam. Analisis uji ANOVA digunakan untuk menguji perbedaan antara kelompok perlakuan.

\section{HASIL}

Penelitian ini menunjukkan, asiaticosida menginduksi proliferasi fibroblas dermis kulit manusia lebih tinggi secara bermakna dibandingkan asam retinoat $(p<0,05)$. Asiaticosida menginduksi sintesis kolagen tipe III lebih tinggi secara bermakna dibandingkan asam retinoat $(p<0,05)$.

\section{KESIMPULAN}

Asiaticosida mampu menginduksi proliferasi fibroblas dermis kulit manusia dan sintesis kolagen tipe I dan III yang dipengaruhi oleh dosis dan waktu inkubasi. Asiaticosida mempunyai efek yang sama seperti asam retinoat pada sintesis kolagen tipe I dan III

Kata kunci: Asiaticosida, kolagen I, kolagen III, fibroblas, proliferasi, asam retinoat

\section{INTRODUCTION}

Skin wound healing is a complex process carried out by cells that are involved in inflammation, re-epithelialization, angiogenesis, granulation, tissue formation and differentiation, and deposition of interstitial matrix. In general, wound healing can be divided into three stages: inflammation, proliferation and remodeling. ${ }^{(1)}$ Centella asiatica (L.)Urb. (CA) has been widely used as traditional herbal medicine in Malaysia, India and Nepal as part of the traditional
Ayurvedic Medicine for hundreds of years. ${ }^{(2,3)}$ It is commonly known as pegaga in Malaysia, pegagan in Indonesia and as penny wort or gotu kola in America. ${ }^{(2-4)}$ This tropical plant can be used as "longevity herb" or herbal anti-aging cosmetic $^{(5,6)}$ and traditionally serves various medicinal purposes such as wound healing, treatment of asthma, ulcers, leprosy, lupus erythematosus, psoriasis, venous disorders, for memory improvement, and as antidepressant, antibacterial, antifungal, and anti-cancer agent. ${ }^{7-}$ 9) 
Centella asiatica has been used traditionally to improve wound healing. ${ }^{(3-5)}$ Centella asiatica ethanolic extract treated wounds can epithelialize faster and have greater collagen content. ${ }^{(9)}$ The biologically active ingredients in CA are triterpenes, namely asiatic acid, madecassic acid, asiaticoside and madecassoside. ${ }^{(8-10)}$ Asiaticoside isolated from CA promotes fibroblast proliferation and extracellular matrix synthesis in wound healing $(11,12)$ by enhancing collagen formation and angiogenesis. ${ }^{(12,13)}$ In particular, asiaticoside and madecassoside stimulate type I and type III collagen, respectively. ${ }^{(12,14)}$ A study by Hadi et al. ${ }^{(13)}$ indicated that allogenic human dermal fibroblasts (HDF) are viable in peripheral blood. Monolayer co-culture in vitro can induce synthesis of type I and III collagen, the major structural and functional components of the skin. Asiaticoside and retinoic acid can regulate (i.e. stimulate or inhibit) the production of these collagens. ${ }^{(11,14)}$

In skin, retinoids are involved in keratinocyte cell differentiation, epidermal cell adhesion and corneocyte exfoliation from the surface of epidermis. More specifically to the dermis, retinoids regulate fibroblast proliferation, induce angiogenesis and play an essential role in the synthesis of collagen and elastin fibrils. ${ }^{(14)}$ Natural products contain a wealth of interesting pharmaceutically active compounds and various active agents are expected to be beneficial in wound healing and as preventive anti-aging cosmetics. ${ }^{(1)}$ The stimulation of collagen synthesis is an important criterion for plant extracts to be considered as a potential ingredient in skin care anti-aging products. ${ }^{(11,12)}$ Due to its ability to stimulate collagen synthesis, CA has been used in skin care products for anti-aging, restoring skin firmness and elasticity and improving skin appearance. $^{(11,12)}$

$\mathrm{Lu}$ et al. ${ }^{(10)}$ reported that asiaticoside isolated from Centella asiatica promotes fibroblast proliferation and extracellular matrix synthesis in wound healing, the precise mechanism, however, being still only partially understood. The aim of this study was to evaluate fibroblast proliferation and type I and III collagen synthesis by asiaticoside as an active compound from CA in comparison to retinoic acid, a wellknown active ingredient in the prevention of skin aging.

\section{METHODS}

\section{Research design}

In the present study, experiments on fibroblast proliferation were conducted at the Laboratory of the Centre for Pharmaceutical and Medical Technology, Agency for the Assessment and Application of Technology, from January 2013 to April 2013, and on collagen synthesis at the Integrated Laboratory of Medicine, Yarsi University, from April 2014 to June 2014.

\section{Preparation of Centella asiatica extract}

Centella asiatica (CA) aqueous and ethanolic extracts (Tawangmangu Strain) and Centella asiatica chitosan nanoparticles were prepared in the laboratory of the Agency for the Assessment and Application of Technology. Centella asiatica was encapsulated in the chitosan nanoparticles by ionotropic gelation. Then, proliferative and cytotoxic effects of nanoencapsulated Centella asiatica extracts was evaluated in vitro on human dermal fibroblasts (HDF). The MTT proliferation assay was performed with the encapsulated CA extracts in comparison with the unencapsulated CA extracts and with empty chitosan nanoparticles (CNP) as controls.

\section{Cell culture and treatment}

Human dermal fibroblast cultures were established individually from preputial skin of an 8 year-old child and prepared at Yarsi laboratorium by Dr. Indra Kusuma. The seventh passages of cultured cells were used for all experiments. Normal human dermal fibroblasts (NHDF) were grown in Roswell Park Memorial Institute (RPMI) medium containing $10 \%$ fetal 
bovine serum (FBS) and 1\% penicillinstreptomycin. Cells were reseeded at a ratio of $1: 3$ and density of $1 \times 10^{6}$ cell $/ \mathrm{mL}$ and subjected to treatment with $0.3125 \mathrm{mg} / \mathrm{mL}, 0.625 \mathrm{mg} / \mathrm{mL}$, $1.25 \mathrm{mg} / \mathrm{mL}, 2.5 \mathrm{mg} / \mathrm{mL}, 5 \mathrm{mg} / \mathrm{mL}$ and $10 \mathrm{mg} /$ $\mathrm{mL}$ of asiaticoside or retinoic acid. The 3-(4,5dimethylthiazol-2-yl)-2,5-diphenyltetrazolium bromide (MTT) assay was repeated three times using MTT as substrate, which is actively absorbed by fibroblasts and then reduced by mitochondrial succinate dehydrogenase under the addition of nicotinamide adenine dinucleotide$\mathrm{H}$ (NADH) from water-soluble MTT to insoluble purple formazan. The number of viable cells was then evaluated at 24 and 48 hours after treatment, as an indicator of fibroblast proliferation. ${ }^{(17)}$ Obtained values were then normalized against the control group, which was taken as $100 \%$.

\section{Type I and III collagen synthetic activity by human dermal fibroblasts}

Collagen synthesis was analyzed using ELISA kit for human collagen type I and III, alpha 1 from Cusabio. Fibroblast collagen synthetic activity was evaluated using ELISA, 24 and 48 hours after treatment and compared with untreated HDF as negative control. Results for collagen synthesis were reported in $\mu \mathrm{g} / \mathrm{mL}$.

\section{Statistical analysis}

For statistical evaluation of HDF proliferation and collagen type I and III synthesis, one-way ANOVA as well as Tukey's post hoc analysis was performed when one-way ANOVA results were significant. Significance was set to $\mathrm{p}<0.05$, and for highly significant differences to $\mathrm{p}<0.001$.

\section{RESULTS}

Table 1 shows that after 24 hours, asiaticoside at all concentrations had stronger effects on HDF proliferation than retinoic acid. The optimal stimulatory effect was observed at $0.625 \mathrm{mg} / \mathrm{mL}$. In statistical analysis with

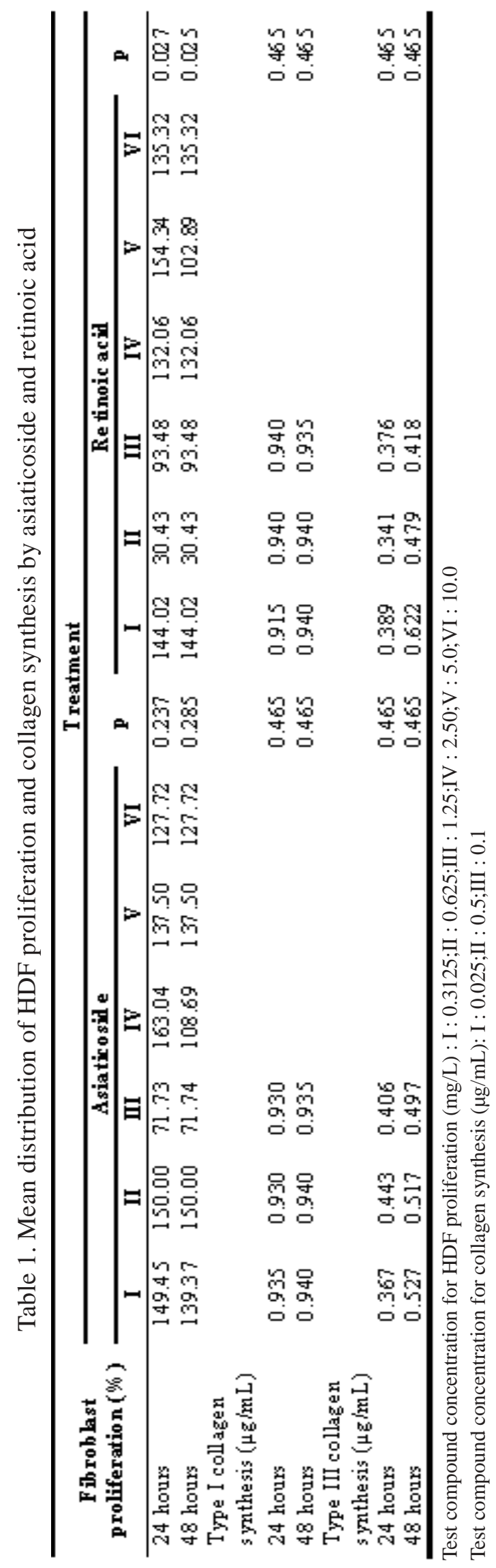


ANOVA test the difference between asiaticoside and retinoic acid was significant $(\mathrm{p}<0.05)$. After 48 hours, asiaticoside has its strongest effect at $0.625 \mathrm{mg} / \mathrm{mL} v s$. retinoic acid $(\mathrm{p}<0.025)$.

The one-way ANOVA test results indicated that between the asiaticoside dose groups there were significant differences in fibroblast proliferation after 24 and 48 hours of treatment $(\mathrm{p}<0.001)$. The post hoc Tukey test found significant differences in the asiaticoside groups at 24 hours, between dose I and II, II and III, II and IV, II and V, II and VI, III and IV, III and VI (Table 2).

According to the one-way ANOVA test, between the retinoic acid dose groups there were significant differences in fibroblast proliferation after 24 hours and 48 hours of treatment ( $\mathrm{p}$ $<0.001)$. The post hoc Tukey test found significant differences in the retinoic acid groups at 24 hours, between dose I and II, I and III, I and V, I and VI, II and III, II and IV, II and V, II and VI, III and V, III and VI (Table 3).

Type I collagen synthesis by HDF after 24 and 48 hours of treatment at all three doses of asiaticoside and retinoic acid, was observed to actually be lower than controls. However, the differences were statistically not significant. For type III collagen production, we observed the greatest induction at 24 hours with asiaticoside treatment at $2.50 \mathrm{ig} / \mathrm{mL}$. On the other hand, at 48 hours the maximum effect was achieved by retinoic acid at $0.50 \mathrm{ig} / \mathrm{mL}$.

Table 2. Post hoc Tukey multiple comparisons on HDF proliferationby asiaticoside

\begin{tabular}{|c|c|c|c|}
\hline & & F hroblast pro lifera tion ( $\%)$ & \\
\hline & & Mean diffe rences & $\mathbf{p}$ \\
\hline 24 ho & & & \\
\hline I & II & -0.54 & 1.000 \\
\hline & III & 77.71 & 0.333 \\
\hline & IV & -13.58 & 0.999 \\
\hline & $\mathrm{V}$ & 11.95 & 0.999 \\
\hline & VI & 21.74 & 0.989 \\
\hline II & III & 78.26 & 0.327 \\
\hline & IV & -13.04 & 0.999 \\
\hline & $\mathrm{V}$ & 12.50 & 0.999 \\
\hline & VI & 22.28 & 0.988 \\
\hline III & IV & -91.30 & 0.197 \\
\hline & $\mathrm{V}$ & -65.76 & 0.978 \\
\hline & VI & -55.97 & 0.919 \\
\hline IV & $\mathrm{V}$ & 25.354 & 0.978 \\
\hline & VI & 35.32 & 0.978 \\
\hline $\mathrm{V}$ & VI & 9.78 & 1.000 \\
\hline 48 ho & & & \\
\hline I & II & -10.62 & 0.999 \\
\hline & III & 67.63 & 0.395 \\
\hline & $\mathrm{IV}$ & 30.68 & 0.937 \\
\hline & $\mathrm{V}$ & 1.87 & 1.000 \\
\hline & VI & 11.65 & 0.999 \\
\hline II & III & 78.26 & 0.259 \\
\hline & IV & 41.30 & 0.818 \\
\hline & $\mathrm{V}$ & 12.5 & 0.999 \\
\hline & VI & 22.28 & 0.983 \\
\hline III & IV & -36.95 & 0.875 \\
\hline & $\mathrm{V}$ & -65.76 & 0.422 \\
\hline & VI & -55.97 & 0.581 \\
\hline IV & $\mathrm{V}$ & -28.80 & 0.951 \\
\hline & VI & -19.02 & 0.992 \\
\hline $\mathrm{V}$ & V I & 9.79 & 1.000 \\
\hline
\end{tabular}

Asiaticoside concentration (mg/L) : I: 0.3125; II: 0.625; III: 1.25; 28.80 IV: 2.50; V: 5.0; VI: 10.0 
Table 3. Post hoc Tukey multiple comparisons on HDF proliferation by retinoic acid

\begin{tabular}{|c|c|c|c|}
\hline & \multicolumn{3}{|c|}{$\begin{array}{c}\text { Fih rob last proliferation (\%) } \\
\text { Mean diferences }\end{array}$} \\
\hline \multicolumn{4}{|c|}{24 hours } \\
\hline \multirow[t]{5}{*}{ I } & II & 113.58 & 0.049 \\
\hline & III & 50.54 & 0.670 \\
\hline & IV & 11.95 & 0.999 \\
\hline & $\mathrm{V}$ & -10.32 & 1.000 \\
\hline & VI & 0.69 & 1.000 \\
\hline \multirow[t]{4}{*}{ II } & III & -63.04 & 0.461 \\
\hline & IV & -101.63 & 0.088 \\
\hline & $\mathrm{V}$ & -123.91 & 0.029 \\
\hline & VI & -104.89 & 0.075 \\
\hline \multirow[t]{3}{*}{ III } & IV & 38.58 & 0.856 \\
\hline & $\mathrm{V}$ & -22.28 & 0.496 \\
\hline & VI & -3.26 & 0.000 \\
\hline \multirow[t]{2}{*}{ IV } & $\mathrm{V}$ & -22.28 & 0.983 \\
\hline & VI & -3.26 & 1.000 \\
\hline $\mathrm{V}$ & VI & 19.02 & 0.992 \\
\hline \multicolumn{4}{|c|}{48 hours } \\
\hline \multirow[t]{5}{*}{ I } & II & 113.58 & 0.025 \\
\hline & III & 50.54 & 0.570 \\
\hline & IV & 11.95 & 0.998 \\
\hline & $\mathrm{V}$ & 41.12 & 0.748 \\
\hline & VI & 8.69 & 1.000 \\
\hline \multirow[t]{4}{*}{ II } & III & -63.04 & 0.353 \\
\hline & IV & -101.62 & 0.049 \\
\hline & $\mathrm{V}$ & -72.46 & 0.229 \\
\hline & VI & -104.88 & 0.041 \\
\hline \multirow[t]{3}{*}{ III } & IV & -38.58 & 0.790 \\
\hline & $\mathrm{V}$ & -9.41 & 0.999 \\
\hline & VI & -41.84 & 0.734 \\
\hline \multirow[t]{2}{*}{ IV } & $\mathrm{V}$ & 29.16 & 0.920 \\
\hline & VI & -3.26 & 1.000 \\
\hline $\mathrm{V}$ & VI & -32.42 & 0.882 \\
\hline
\end{tabular}

Retinoic acid concentration (mg/L) : I : 0.3125; II : 0.625; III : 1.25; IV : 2.50; V : 5.0; VI : 10.0

\section{DISCUSSION}

Our results indicate that 24 hours after treatment, asiaticoside has a stronger effect on fibroblast proliferation at all concentrations compared to retinoic acid. This is in accordance to the previous study by Lu et al., ${ }^{(10)}$ in which they reported alterations in COL18A1, COL1A2, and COL3A1 gene profile, as well as in the fibroblast cell division cycle, in response to asiaticoside stimulation.

Gimemo et al. ${ }^{(15)}$ investigated the timedependency effect of four different retinoids in the $\mu \mathrm{M}$ dose range on human dermal fibroblasts cultivated in vitro. This study showed that retinol and retinal at concentrations greater than $20 \mu \mathrm{M}$, can damage cells as evaluated by lactate dehydrogenase activity released into the culture medium, and induce oxidative stress and apoptosis in human dermal fibroblasts.

Type I and III collagens are major structural and functional components of skin connective tissue. Therefore, we investigated the intracellular and extracellular modifications of type I and III collagen, as in the cross-linked step by asiaticoside stimulation. ${ }^{(11)} \mathrm{Hadi}$ et al. ${ }^{(13)}$ investigated allogeneic HDF viability in peripheral blood mononuclear co-culture and reported that allogeneic HDF were able to secrete type I and III collagen. Our study showed that 
asiaticoside and retinoic acid induced the synthesis of type I collagen in HDF after 24 and 48 hours of incubation, but after 24 hours 0.05 $\mu \mathrm{g} / \mathrm{mL}$ of asiaticoside induced in HDF significantly higher type III collagen synthesis compared to retinoic acid.

Our experiment indicated that after 24 hours, type III collagen synthesis in HDF was significantly higher after treatment with asiaticoside compared to retinoic acid and controls (without treatment). Maximal effect was achieved at $2.50 \mu \mathrm{g} / \mathrm{mL}$ of asiaticoside, but after 48 hours retinoic acid had a greater effect than asiaticoside at the same dose. ${ }^{(7)}$

A study in Malaysia showed that CA extract has a dose-dependent stimulatory effect on collagen synthesis, which was enhanced threefold over controls at a dose of $50 \mathrm{mg} / \mathrm{mL}$. ${ }^{(5)}$ Compared to our experiment, another study in Malaysia by Hashim et al. ${ }^{(4)}$ evaluated the effect of Centella asiatica on collagen synthesis in $\mathrm{HDF}$, compared to vitamin $\mathrm{C}$. The effect of CA extract was stronger than that of vitamin $C$, which was used as a positive control. The CA extract at $50 \mathrm{mg} / \mathrm{mL}$ showed three-fold collagen enhancement, whereas vitamin $\mathrm{C}$ had a two-fold collagen enhancing response. ${ }^{(4)}$

Lu et al. ${ }^{(10)}$ showed that asiaticoside isolated from CA induced collagen III synthesis with maximum effect at 48 hours. In our study, both asiaticoside and RA showed greatest effects at 48 hours. This is supported by the previous study of $\mathrm{Wu}$ et al., ${ }^{(16)}$ which reported significant elevation of procollagen III level following stimulation with low concentrations of asiaticoside and madecassoside. Moreover, research by Pareda et al. ${ }^{(17)}$ indicated a dosedependent in vitro stimulation on collagen synthesis by green Coffea arabica (GCO). It was found that collagen synthesis was enhanced 1.8 fold in human dermal fibroblasts than in negative controls after 48 hours of treatment with 3.125 $\mathrm{mg} / \mathrm{mL}$ and $6.25 \mathrm{mg} / \mathrm{mL}$ GCO. These results demonstrated a more pronounced stimulatory effect of biosynthetic compounds on collagen production. Nevertheless, with further improvement, we expect a similar stimulatory performance of asiaticoside.

Song et al. ${ }^{(18)}$ conducted a study of madecasoside (one of the active compounds of Centella asiatica) and found that this compound induces apoptosis of keloid fibroblasts in a mitochondrial-dependent pathway, in addition to inhibiting type I collagen synthesis. Our study with asiaticoside matches this observation, with greater type III collagen and lower type 1 collagen synthesis in human dermal fibroblast cultures of preputium explants of young children (4-8 years). Ju-lin et al. ${ }^{(19)}$ had previously reported that asiaticoside induces the expression and activation of the TGF-â signaling pathway in hyperthropic scars, while inhibiting Smad7. This is the underlying mechanism behind the decreased type I collagen production. In the present study, however, we isolated human dermal fibroblast from one subject only. Therefore, this may not fully represent some genetic variations related with collagen synthesis. A clinical study by Kaji et al. ${ }^{(20)}$ concluded that topical retinol treatment for 24 weeks improved fine wrinkles associated with natural aging, and that increased collagen production by retinol is the most likely reason behind it. Clinical application of the present study will be done to investigate the effect of asiaticoside in accelerating wound healing. Another possible clinical study is to investigate the anti-aging effect of asiaticoside after topical treatment, in comparison with retinoic acid.

\section{CONCLUSIONS}

Asiaticoside induces HDF cell proliferation and collagen synthesis in a time- and dosedependent manner. Asiaticoside as an active agent of Centella asiatica has a similar effect as retinoic acid on type I and III collagen synthesis in human dermal fibroblasts.

\section{CONFLICT OF INTEREST}

The authors have no conflict of interest. 


\section{ACKNOWLEDGEMENTS}

The authors wish to thank Intan Razari and Dani for laboratory assistance, dr. Indra Kusuma for HDF cell culture and dr. Pras for providing pure asiaticoside from the Agency for the Assessment and Application of Technology (Badan Pengkajian dan Penerapan Teknologi BPPT).

\section{REFERENCES}

1. Davis SC, Perez R. Cosmeceutical and natural products: wound healing. Clin Dermatol 2009; 27:502-6.

2. Chanchal D, Swarniata S. Novel approaches in herbal cosmetics. J Cosmet Dermatol 2008;7:8995.

3. Tiwari S, Geniot S, Gambhir IS. Centella Asiatica: a concise drug review with probable clinical uses. J Stress Physiol Biochem 2011;7: 39-42.

4. Hashim P, Sidek H, Helan MHM, et al. Triterpene composition and bioactivities of Centella asiatica. Molecules 2011;16:1310-22.

5. Pitella F, Dutra RC, Junior DD. Antioxidant and cytotoxic activities of Centella asiatica (L) Urb. Int J Mol Sci 2009;10:3713-21.

6. Paocharoen V. The efficacy and side effects of oral Centellla asiatica extract for wound healing promotion in diabetic wound patients. $\mathrm{J}$ Med Assoc Thai 2010;93:S166-9.

7. Zainol NA, Voo SC, Sarmidi MR, et al. Profiling of Centella asiatica (L.) Urban extract. Malaysian J Anal Sci 2008;12;322-7.

8. Gohil KJ, Patel JA, Gajjar AK. Pharmacological review on Centella asiatica: a potential herbal cure-all. Indian J Pharm Sci 2010;72:546-56.

9. Bhavna D, Jyoti K. Centella asiatica: the elixir of life. IJRAP 2011;2:431-8.

10. Lu L, Ying K, Wei S, et al. Asiaticoside induction for cell-cycle progression, proliferation and collagen synthesis in human dermal fibroblasts. Int J Dermatol 2004;43:801-7.
11. Loc NH, Tam An NT. Asiaticoside production from Centella (Centella asiatica L. Urban) cell culture. Biotechnol Bioprocess Engineering 2010;15:1065-70.

12. Lintner K, Chamberlin CM, Modun P, et al. Cosmeceuticals and active ingredients. Clin Dermatol 2009;27:461-8.

13. Hadi RS, Kusuma I, Sandra Y. Allogenic human dermal fibroblast are viable in peripheral blood mononuclear co-culture. Univ Med 2014;33:3442.

14. Jurzak M, Latocha M, Goiniczek K. Influence of retinoids on skin fibroblasts metabolism in vitro. Acta Pol Pharm Drug Res 2008;1:85-95.

15. Gimeno A, Zarogoza R, Vivosese I. Retinol at concentration greater than the physiological limit, induces oxidative stress and apoptosis in human dermal fibroblast. Exp Dermatol 2004; 13:45-54.

16. Wu F, Bian D, Xia Y, et al. Identification of major active ingredients responsible for burn wound healing of Centella asiatica herbs. J Evid Based Complement Altern Med 2012. Article ID 848093, 13 pages. doi:10.1155/2012/848093.

17. Pareda MDCV, Dieamant GDC, Eberlin S, et al. Effect of green Coffea Arabica L. seed oil on extracellular matrix components and waterchannel expression in in vitro and ex vivo human skin models. J Cosmetic Dermatol 2009;8:5862.

18. Song J, Day Y, Bian D, et al. Madecassoside induce apoptosis of keloid fibroblast via a mitochondria-dependent pathway. Drug Dev Res 2011;72:315-22.

19. Ju-lin X, Shao-hai Q, Tian-zeng L, et al. Effect of asiaticoside on hypertrophic scar in the rabbit ear model. J Cutan Pathol 2009;36:234-9.

20. Kaji R, Kwak HSR, Schumacker WE, et al. Improvement of naturally aged skin with vitamin A (retinol). Arch Dermatol 2007;143: 606-12. 